\title{
SARS-CoV-2 downregulation of ACE2 and pleiotropic effects of ACEIs/ARBs
}

\author{
Michele M. Ciulla ${ }^{1}{ }^{1}$
}

Received: 12 May 2020 / Revised: 15 May 2020 / Accepted: 17 May 2020 / Published online: 10 June 2020

(c) The Japanese Society of Hypertension 2020

Following the concerns triggered by the emergence of SARS-CoV-2 and the COVID-19 pandemic with its high mortality rate, mainly in older people with one or more cardiovascular comorbidities [1], the community of cardiologists and hypertensiologists has been struck by the doubt that one of the cornerstones of cardiovascular therapy could be a Trojan horse. This nightmare explains the incontrovertible fact that SARS-CoV-2 uses ACE2 as a functional receptor to enter human cells [2], and it is supposed that ACEIs/ARBs upregulate ACE2. I emphasize supposed since the studies published to date demonstrating this upregulation are, indeed, very few; without the ambition of a systematic review, by querying Medline, I found only seven studies, mainly on experimental animal models and in vitro studies, supporting the upregulation of the ACE2/Ang 1-7/MasR axis [3-9], and this was clearly stated in a recent paper published by Hypertension Research [10]. The reason why this upregulation is so desired by cardiologists depends on having hypothesized for a long time that some of the favorable effects of ACEIs/ARBs in treating arterial blood pressure, ischemic heart disease, and heart failure are mediated by ACE2; therefore, these elusive effects have been defined as pleiotropic. Indeed, "the puzzle of sharing biomolecular targets between coronaviruses and mediators of the cardiovascular system in humans" [11] has been followed by several commentary-style papers discussing the replacement of ACEIs/ARBs in individuals with COVID-19 $[12,13]$. The main scientific societies have stigmatized any therapeutic change in the absence of supporting data, endorsing the "status quo" of cardiovascular therapy [14].

Michele M. Ciulla

michele.ciulla@unimi.it

1 Laboratory of Clinical Informatics and Cardiovascular Imaging, Department of Clinical Sciences and Community Health, University of Milan, Milan, Italy
Indeed, there is another scenario: the downregulation of ACE2, mediated by SARS-CoV-2, might be the causative factor for the severe lung complications responsible for the high mortality rates, but ACEIs/ARBs are still a candidate to increase ACE2 in individuals with COVID-19? In this regard, a very recent retrospective multicenter study published online by Circulation Research [15] focused on assessing the mortality rates in COVID-19 patients with hypertension, treated with or without ACEIs/ARBs, seems to solve the puzzle, but unfortunately, it only adds other unsolved questions because of methodological flaws. In summary, it is not possible to ascribe the merit of the lower mortality rate to the ACEI/ARB arm since the number of patients taking diuretics was significantly higher than that in the non-ACEI/ARB group (30.9 vs $12.8 \% ; p<0.001)$, and this is also true for beta-blockers (28.2 vs $17.9 \%$; $p<$ 0.005). Furthermore, some differences, with significant $p$ values, are reported for comorbidities on admission. Thus, the ACEI/ARB arm is slightly different, but blood pressure control seems optimal for both groups. Having long supposed that the superiority of the effects of ACEIs/ ARBs on target organs is related to their pleiotropic effects, the idea that these effects are related to the concurrent use of diuretics/beta-blockers is quite disappointing, and what about the drugs responsible for the worsening effect in the non-ACEI/ARB arm? The effects of these drugs are impossible to determine since the use of calcium channel blockers was not significantly different between the two groups ( 54.8 vs $52 \% ; p=\mathrm{ns}$ ) and since the proportion of individuals taking alpha-blockers in both groups was the same. Thus, the underlying pathophysiological mechanism and the management of COVID-19 are still to be demonstrated with better evidence. In conclusion, since it is not disputable that SARS-CoV-2 uses ACE2 to enter the host and, possibly, that it downregulates ACE2 while using it, we can speculate that ACEIs/ARBs exert their pleiotropic effects on the target organ [16] mainly by modulating the cytokine cascade via other mechanisms in response to damage [17, 18]. 
Author contributions The author fulfills the ICMJE criteria for authorship.

\section{Compliance with ethical standards}

Conflict of interest The author declares that he has no conflict of interest.

Publisher's note Springer Nature remains neutral with regard to jurisdictional claims in published maps and institutional affiliations.

\section{References}

1. Guan WJ, Ni ZY, Yu H, Wen-Hua Liang WH, Chun-Quan Ou CQ, Jian-Xing He JX, et al. Clinical characteristics of coronavirus disease 2019 in China. N Engl J Med. 2020;382:1708-20. https:// doi.org/10.1056/NEJMoa2002032.

2. Liu Z, Xiao X, Wei X, Wei X, Li J, Yang J, et al. Composition and divergence of coronavirus spike proteins and host ACE2 receptors predict potential intermediate hosts of SARS-CoV-2. J Med Virol. 2020. https://doi.org/10.1002/jmv.25726.

3. Graus-Nunes F, Santos FO, Marinho TS, Miranda CS, Barbosada-Silva S, Souza-Mello V. Beneficial effects of losartan or telmisartan on the local hepatic renin-angiotensin system to counter obesity in an experimental model. World $\mathbf{J}$ Hepatol. 2019;11:359-69. https://doi.org/10.4254/wjh.v11.i4.359.

4. Abuohashish HM, Ahmed MM, Sabry D, Khattab MM, Al-Rejaie SS. ACE-2/Ang1-7/Mas cascade mediates ACE inhibitor, captopril, protective effects in estrogen-deficient osteoporotic rats. Biomed Pharmacother. 2017;92:58-68. https://doi.org/10.1016/j. biopha.2017.05.062.

5. Vuille-dit-Bille RN, Camargo SM, Emmenegger L, Sasse T, Kummer E, Jando J, et al. Human intestine luminal ACE2 and amino acid transporter expression increased by ACE-inhibitors. Amino Acids. 2015;47:693-705. https://doi.org/10.1007/s00726014-1889-6.

6. Liu $\mathrm{CX}, \mathrm{Hu} \mathrm{Q}$, Wang Y, Zhang W, Yong MA, Bo J, et al. Angiotensin-converting enzyme (ACE) 2 overexpression ameliorates glomerular injury in a rat model of diabetic nephropathy: a comparison with ACE inhibition. Mol Med. 2011;17:59-69. https://doi.org/10.2119/molmed.2010.00111.

7. Huang ML, Li X, Meng Y, Xiao B, Ma Q, Ying SS, et al. Upregulation of angiotensin-converting enzyme (ACE) 2 in hepatic fibrosis by ACE inhibitors. Clin Exp Pharm Physiol. 2010;37:e1-6. https://doi.org/10.1111/j.1440-1681.2009.05302.x.
8. Ye R, Liu Z. ACE2 exhibits protective effects against LPSinduced acute lung injury in mice by inhibiting the LPS-TLR4 pathway. Exp Mol Pathol. 2020;113:104350. https://doi.org/10. 1016/j.yexmp.2019.104350.

9. Wang LH, Dong T, Liu BB, Zhao XD, Chen JW, Murao K, et al. Contribution of the renin-angiotensin system in chronic footshock induced hypertension in rats. Life Sci. 2015;121:135-44. https://doi.org/10.1016/j.lfs.2014.12.004.

10. Kai H, Kai M. Interactions of coronaviruses with ACE2, angiotensin II, and RAS inhibitors-lessons from available evidence and insights into COVID-19. Hypertens Res. 2020;1-7. https://doi. org/10.1038/s41440-020-0455-8.

11. Ciulla MM. The puzzle of sharing bio-molecular targets between coronaviruses and mediators of the cardiovascular system in humans: looking for plausible hypotheses. Med Hypotheses. (2020). https://doi.org/10.1016/j.mehy.2020.109793.

12. Esler M, Esler D. Can angiotensin receptor-blocking drugs perhaps be harmful in the COVID-19 pandemic? J Hypertens. 2020. https://doi.org/10.1097/HJH.0000000000002450.

13. Roncati L, Gallo G, Manenti A, Palmieri B. Renin-angiotensin system: the unexpected flaw inside the human immune system revealed by SARS-CoV-2. Med Hypotheses. 2020;140:109686. https://doi.org/10.1016/j.mehy.2020.109686.

14. American Heart Association (AHA), Heart Failure Society of America (HFSA), American College of Cardiology (ACC). Patients taking ACE-i and ARBs who contract COVID-19 should continue treatment, unless otherwise advised by their physician. 2020. https://newsroom.heart.org/news/patients-taking-ace-i-and-a rbs-who-contract-covid-19-should-continue-treatment-unlessotherwise-advised-by-their-physician.

15. Zhang P, Zhu L, Cai J, Fang L, Qin JJ, Jing Xie J, et al. Association of inpatient use of angiotensin converting enzyme inhibitors and angiotensin II receptor blockers with mortality among patients with hypertension hospitalized with COVID-19. Circ Res. 2020. https://doi.org/10.1161/CIRCRESAHA.120.317134.

16. Cheng $\mathrm{H}$, Wang $\mathrm{Y}$, Wang GQ. Organ-protective effect of angiotensin-converting enzyme 2 and its effect on the prognosis of COVID-19. J Med Virol. 2020. https://doi.org/10.1002/jmv.25785.

17. Ciulla MM, Montelatici E, Ferrero S, Braidotti P, Paliotti R, Annoni G, et al. Potential advantages of cell administration on the inflammatory response compared to standard ACE inhibitor treatment in experimental myocardial infarction. $\mathrm{J}$ Transl Med. 2008;6:30. https://doi.org/10.1186/1479-5876-6-30.

18. Ciulla MM, Paliotti R, Esposito A, Dìez J, López B, Dahlöf B, et al. Different effects of antihypertensive therapies based on losartan or atenolol on ultrasound and biochemical markers of myocardial fibrosis: results of a randomized trial. Circulation 2004;110:552-7. 